\title{
Contribution of Social Media Addiction on Ethics for Communicating Students to Lecturers
}

\author{
Ristra Sandra Ritonga ${ }^{1} \&$ Agung Tri Prasetia ${ }^{2}$ \\ ${ }^{1}$ Universitas Pembangunan Panca Budi Medan \\ ${ }^{2}$ Institut Agama Islam Negeri Kerinci \\ e-mail: ristrasandraritonga18@gmail.com.
}

\begin{abstract}
Abstrak. Media sosial kini telah menjadi salah satu kebutuban remaja. Kecanduan media sosial pada remaja terutama siswa dapat mempengarubi kehidupan sosial, terutama dalam Aspek komunikasi baik secara langsung atau melalui pesan singkat. Khusus di perguruan tinggi, mahasiswa tidak pernah bebas berkomunikasi dengan dosen. Sebagian besar mahasiswa yang kecanduan media sosial mengirim pesan singkat ke Dosen sebagaimana ia mengirim pesan singkat kepada temannya di media sosial. Penelitian ini bertujuan untuk melihat seberapa besar pengaruh kecanduan media sosial terhadap etika komunikasi mahasiswa terhadap dosen. Sampel dalam penelitian ini yakni mahasiswa yang dipilih dengan menggunakan teknik random sampling. Instrumen yang digunakan dalam penelitian ini adalah skala kecanduan media sosial dan etika komunikasi. Dampak kecanduan media sosial terhadap etika komunikasi mahasiswa kepada dosen berada pada tingkat sedang.
\end{abstract}

Kata Kunci: Media Sosial, Komunikasi, Etika

\begin{abstract}
Abstrak. Social media has now become one of the needs of teenagers. Addiction to social media in adolescents especially students can influence social life, especially in terms of communication either directly or through short messages. In life in the world of universities, students are never free to communicate with lecturers. Most students who are infected with social media addiction send a short message to the Lecturer as well as how he sent a short message to his friend on social media. This research aims to see how much the contribution of social media addiction to the communication ethics of students to lecturers is given. The sample in this study was specifically given to students using random sampling. The instrument used in this study was social media addiction and communication ethics. The significance of the contribution of social media addiction to the ethics of communicating students to lecturers is at a moderate level.
\end{abstract}

Key Word : Social Media, Communication, Ethics 


\section{INTRODUCTION}

This Industry 4.0 revolution era is an era that lives life using all technology, social media is one of the most important needs for many people. Not infrequently also social media is now one that helps us to be able to know and connect with the outside world. Many also say that the presence of social media can bring a far closer, but not infrequently it can distance the near ones. The development of the internet and social media is so fast that brings various impacts both positively and negatively to the people who use it, including teenagers (Syamsoedin, Bidjuni, \& Wowiling, 2015). Basically social media is the latest development of new web technologies that can be used if connected to the internet network, which is able to facilitate all people to be able to communicate, participate, share even though they are in different cities or countries (Azizan, 2016; Cahyono, 2011; Irianti, 2017).

Living in the era of globalization, adolescents are those who often use social media in their daily lives and spend more of their free time playing social media so that social media is used as a lifestyle for adolescents (Juwita, Budimansyah, \& Nurbayani, 2013). The development of social media certainly has an impact on its users, both positive and negative impacts. The impact we will receive depends on how we use social media itself, if we can control the use towards the good and not fall into addiction then the positive impact we will get, and vice versa. The positive impact of social media is socializing with many people and also can facilitate users in learning activities because it is used as a means of discussion (Khairuni, 2016). While the negative effects of social media addiction are teenagers making social media a necessity, rarely communicating in the real world, making adolescents especially students negligent in doing assignments, and making students less ethical in communicating with their lecturers when doing text messages (Irianti, 2017).

TNS Chief Development Officer Mathew Froggat revealed that the internet has become an important part of life in the 21st century. The results of research conducted by Charp in 2000 said that $50 \%$ of homes in America can be said to be connected via the internet every hour (Alyusi, 2016). The Ministry of Education in Japan estimates that around 518,000 children in 2013 in the 12-18 year age range experienced addiction to the internet and social media (Soliha, 2015).

Indonesia itself has eight major cities that have the highest levels of internet addiction and social media in 2013. One of the highest levels of cities is Jakarta, which has a percentage of 64\% of Indonesia's population. social media that are currently rife in Indonesia are WhatsApp, Instagram, and Facebook (Barnett \& Cothern, 2011). Social media can change the social life of 
the community, these changes become an attraction that affects millions of people in the world to get to know social media (Cahyono, 2011; Deiratri, Karini, \& Machmuroch, 2015).

Research conducted in the United Kingdom explains that too many negative effects caused by social media addiction, one of which is that users of social media that are too excessive can cause depression. In the results of a study published by the journal Psychopathology, which was chaired by Moriso (2010), it was explained that social media addicts were more likely to develop mental illness (Deiratri et al., 2015; Gok, 2016). Individuals who are said to be depressed due to social media addiction are more likely to watch videos excessively and seek social support for chat rooms on social media to feel that they are considered to exist (He et al., 2017). Susan Baer also researched 102 students who were in the age range of 11-17 years who were outpatients in a psychiatric clinic in Canada. The results of his research state that there are $94 \%$ of teens spend more than 2 hours/day in front of the screen of a smartphone or computer. The America Academy of Pediatrics recommends that smartphone users be in front of the screen no more than 2 hours/day (AAP, 2001). But based on the results of research, the average teenager spends his activities playing social media for approximately 6-7 hours/day (Barnett \& Cothern, 2011).

Social media addiction has many effects that can cause individuals to grow towards negative developments. Teenagers who have social media usually post about their activities, vent, and photos of their daily activities with friends, family and themselves. One negative impact caused by social media addiction is that it can interfere with life and ethics in communication (Secsio, Putri, Nurwati, \& S, 2016). This often happens to students who are accustomed to communicating on social media so that they are not often carried away when communicating with lecturers who should use polite language.

As research conducted in Banjarmasin explained that most students choose to use mixed language styles when communicating with lecturers through social media. the style of mixed language in question is that students use formal language styles and relaxed language styles, this can lead to a shift in the culture of communication that could have a less positive impact on the educational environment (Nikmah, Rahwani, \& Fitriani, 2018). The next study also explained that students who contact lecturers are usually related to thesis guidance, but some students use casual language in sending short messages to their lecturers such as using the word "I", abbreviating the word "tomorrow", etc. ( Wida, 2014).

Based on the results of the research most of the remedies do communication through social media accounts like Facebook as much as $36.8 \%$, this is done by teenagers around 3 to 5 times a day (Majorsy, Kinasih, Andriani, \& Lisa, 2013). While in conducting social interaction ethics in communication is the most important thing in establishing good relationships between 
individuals, organizations and the relationship of service institutions such as students with lecturers (Falimu, 2017).

Social media is a website and also an application that can allow users to create various content such as exchanging messages, pictures, and videos (Kurcaburun, 2016). Social media has various content such as various types that have the purpose of connecting people from various parts of the world, namely: Facebook, Youtube, Instagram, Line, Whatsapp, and Blackberry Messenger (Barnett \& Cothern, 2011; Bozanta, 2017). In living their lives for special teenage days Students always live with the social media they have on smartphones, whether it's just chatting or looking at other people's social media accounts. Social media addiction was first discovered by Ivan Goldberg, who described the symptoms that arise are: (1) often forget the time, (2) symptoms of withdrawal from the social environment or life in the real world); (3) the emergence of a high need for accessing social media; and (4) the increasing level of ethics and values in social interaction in community life (Nurmandia \& Wigati, 2013).

Social media addiction can have a negative impact on users who play over time both socially, psychologically, and physically (Solema (in Rahmi, 2017). One of the problems that often occurs in students is the lack of ability to distinguish how to communicate through social media with friends and lecturers Most students generalize communication ethics through short messages both to peers and lecturers, small things that often happen students do not have ethics in communicating with lecturers in terms of time to send short messages and also polite writing methods (Putra, 2018). This makes the lecturers complain that the students do not respect the lecturers by sending short messages such as "Sir, my guidance student wants to meet with you, can you be found now?" And many more sentences which according to the lecturer were not ethical to do between lecturers and omniscience students.

Ethics is the application of moral philosophical processes and theories in real situations that are centered on the basic principles and concepts that human beings in thinking and actions are based on values that apply both in the community and in the institution's environment (Familu, 2017). The communication process occurs almost every time we carry out activities, both among educated people and primitive people who have never known education at all (Rosanti, 2019). Therefore in the world of education, especially the ethics of contacting lecturers is so important for students. The communication ethics in question is communication using an intermediary for cellphones or cellphones, which sees the ability of students who have started to communicate great through mobile phones (Putra, 2018). 


\section{METHOD}

This research is a quantitative approach with descriptive method. The statistical method used in this study is correlational which aims to test the forecasting analysis of the value of the contribution or influence of the independent variable on the dependent variable to prove the causal relationship. The sampling technique used was purposive sampling. So that the study sample was 150 students.

The instrument used in uncovering social media addiction and the ethics of student communication in contacting lecturers. Data analysis techniques use simple regression with SPSS version 20.0.

\section{RESULT AND DISCUSSION}

\section{Result}

The results of the study state that social media addiction and student communication ethics to lecturers are at a moderate stage. With the percentage in the variable social media addiction, $72.71 \%$ which is at the moderate level and the student's communication ethics on the lecturer is in the moderate stage with a percentage of $68.13 \%$. From the results of the above percentage, it states that the ethics of communicating students with lecturers can be overcome with reduced duration of social media playing and can be distinguished how to communicate on social media which is almost the average peers with lecturers who are the same level as our parents. This can be seen from the contribution given by social media addiction to the ethics of communicating students with lecturers.

Table 1. <Results of Regression Analysis and Significance Test>

\begin{tabular}{cccc}
\hline Model & $\mathrm{R}$ & $\mathrm{R}$ Square & Sig. \\
\hline $\mathrm{X}-\mathrm{Y}$ & 0.554 & 0.307 & 0.000 \\
\hline
\end{tabular}

Based on the table above shows that the contribution of social media addiction to the ethics of communicating students to lecturers is in the high category that is equal to $30.7 \%$. This explains that individuals who tend to be addicted to social media and spend their time communicating through social media can influence the ethics of communicating to lecturers in terms of communication through cellphones or short messages.

\section{Discussion}

\section{Social Media Addiction}

The results of the descriptive analysis of the score with an average percentage of $72.71 \%$, indicating the level of addiction to social media is in the medium category. Cao \& Su (2006) 
explain that someone addicted to social media is easily influenced by feelings, emotional, unstable, imaginative, deep in thought, independent, experimenting, and prefers his own decisions.

2. Ethics of Student Communication to Lecturers

The results of the descriptive analysis of the score with an average percentage of $68.13 \%$, indicating the level of ethics of student communication on lecturers is in the medium category. Communication ethics is often a problem among educational institutions, especially when students want to send short messages to lecturers with the aim of guidance or just delivering assignments.

3. Contribution of Social Media Addiction to the Ethics of Student Communication to Lecturers

Based on the results of the data analysis, it was shown that social media addiction contributed significantly to the ethics of student communication at the Lecturer by $30.7 \%$. This means that social media addiction has a role in the ethics of student communication to lecturers. $39.3 \%$ were influenced by these factors including personality factors, environmental factors, interactional factors, and situational factors.

\section{CONCLUSIONS}

Based on the findings and discussion of the results of the study, then conclusions can be stated as follows:

1. The description of social media addiction in students whose age range is 19-21 years is in the medium category.

2. An overview of the ethics of student communication on lecturers who in this case the communication meant is communication through short messages in the medium category.

4. 3.Addiction to social media contributed $30.7 \%$ with the medium category. This can explain that in order to improve students' understanding of the ethics of communication with lecturers, students must be able to reduce the level of playing social media.

\section{REFERENCES}

Azizan, H. (2016). Pengaruh Kepercayaan Diri Terhadap Ketergantungan Media Sosial Pada Siswa Di SMK Negeri 1 Bantul, 1-10.

Barnett, B., \& Cothern, K. (2011). Social Media Use: An Exploratory Test of Effects on the Daily Lives of College Students, 1(1), 9-16. 
Bozanta, A. (2017). The Effects Of Social Media Use On Collaborative Learning: A Case Of Turkey, (January), 96-110.

Cahyono, A. S. (2011). Pengaruh Media Sosial Terhadap Perubahan Sosial Masyarakat Di Indonesia, 140-157.

Deiratri, T., Karini, S., \& Machmuroch. (2015). Hubungan Antara Kecanduan Internet dan Depresi Pada Mahasiswa Pengguna Warnet di Kelurahan Jebres Surakarta, 4(1), 75-84.

Falimu. (2017). Etika Komunikasi Pegawai terhadap Pelayanan Penerbitan Pajak Bumi dan Bangunan. Jurnal Komunikator, 9(1).

Gok, T. (2016). The Effects of Social Networking Sites on Students' Studying and Habits The Effects of Social Networking Sites o n Students' Studying and Habits.

He, W., Qi, A., Wang, Q., Wu, H., Zhang, Z., Gu, R., \& Luo, W. (2017). Abnormal Reward and Punishment Sensitivity. Computers in Human Behavior. https://doi.org/10.1016/j.chb.2017.06.017

Irianti, E. (2017). Dampak Ketergantungan Media Sosial Pada Kalangan Dystopian dan Utopian, 1, 67-78.

Juwita, E. P., Budimansyah, D., \& Nurbayani, S. (2013). Peran Media Sosial Terhadap Gaya Hidup Siswa SMA Negeri 5 Bandung.

Khairuni, N. (2016). Dampak Positif dsn Negatif Sosial Media Terhadap Pendidikan Akhlak Anak, 2(1), 91-106.

Kurcaburun, K. (2016). Self-Esteem , Daily Internet Use and Social Media Addiction as Predictors of Depression among Turkish Adolescents, 7(24), 64-72.

Majorsy, U., Kinasih, A. D., Andriani, I., \& Lisa, W. (2013). Hubungan Antara Keterampilan Sosial dan Kecanduan Situs Jejaringan Sosial Pada Masa Dewasa Awal, 5, 8-9.

Nikmah, N., Rahwani, N. R., \& Fitriani. (2018). Etika Komunikasi Mahasiswa kepada Dosen (Studi pada Mahasiswa Akuntansi Politeknik Negeri Banjarmasin), 6014, 365-372.

Nurmandia, H., \& Wigati, D. (2013). Hubungan Antara Kemampuan Sosialisasi Dengan Kecanduan Jejaring Sosial, 4(2), 107-119.

Putra, F. (2018). Etika Komunikasi Mahasiswa kepada Dosen Melalui Aplikasi Pesan Teks dalam Urusan Akademik.

Rosanti, D. (2019). Etika Komunikasi Mahasiswa Aktivis Kampus di Universitas Islam Negeri Sunan Ampel Surabaya.

Secsio, W., Putri, R., Nurwati, R. N., \& S, M. B. (2016). 7 Pengaruh Media Sosial terhadap Perilaku Remaja, 3(1), 1-54.

Soliha, S. F. (2015). Tingkat Ketergantungan Pengguna Media Sosial dan Kecemasan Sosial, 1-10.

Syamsoedin, W., Bidjuni, H., \& Wowiling, F. (2015). Hubungan Durasi Penggunaan Media Sosial Dengan Kejadian Insomnia Pada Remaja Di SMA Negeri 9 Manado, 3.

Wida, E. (2014). Perilaku Komunikasi Mahasiswa di Messenger Application, 20-26. 